\title{
EFFECT OF SEWAGE SLUDGE AND SAWDUST IN ASSOCIATION WITH HYBRID RYEGRASS (Lolium $\times$ hybrydum HAUSSKN.) ON SOIL MACROAGGREGATES AND WATER CONTENT
}

\author{
Marco Sandoval E. ${ }^{1}$, José Celis H. ${ }^{2 *}$, and Carlos Bahamondes $\mathbf{P}^{1}$.
}

\begin{abstract}
Chilean soils degradation is a serious problem affecting directly the productivity of most of the crops. Some evidence indicates sewage sludge can improve soil physical properties, especially when combined with sawdust. The objective of this work was to evaluate the effect of different mixtures of sewage sludge (LU) and sawdust (RA) on water-stable aggregates and available water content of a degraded Alfisol cropped with hybrid ryegrass (Lolium $\times$ hybridum Hausskn.), under greenhouse conditions. The experimental design was a completely randomized with a factorial arrangement of 2

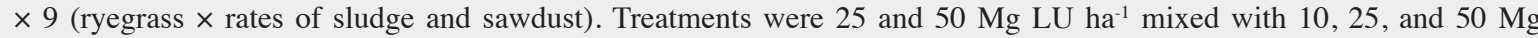
RA ha-1 . Ratio mixtures of LU/RA were set in pots with hybrid ryegrass. Soil available water content (AW), percentage of macroaggregates (MA) and water-stable aggregates (AWD) were evaluated. Ryegrass aboveground biomass was also measured. Mixtures of LU/RA amended to the soil increased MA and AWD, an effect that was most evident at $50 \mathrm{Mg}^{-1}$. The AW value was greater when LU was amended to $50 \mathrm{Mg} \mathrm{ha}^{-1}$ mixed with RA at doses of 10,25 , and $50 \mathrm{Mg}^{-1}$. There was greater aboveground biomass of hybrid ryegrass, directly related to increasing doses of LU and RA in the mixtures. The addition to soil of both organic residues combined, LU and RA, improved the physical parameters studied, especially in the presence of hybrid ryegrass.
\end{abstract}

Key words: Soil aggregation, biosolids, remediation, organic wastes, degraded soil.

$I^{\prime}$ is estimated that $46 \%$ of Chilean territory, over 34 million hectares, presents some degradation problem (Pérez y González, 2001). About 2 million hectares of Alfisols located between $32^{\circ}$ and $38^{\circ} \mathrm{S}$ lat have a high degree of water erosion, mainly due to aggressive agricultural practices, with total loss of the horizon $\mathrm{A}$ and an important part of horizon B (Sandoval et al., 2011). Degraded soils have poor aeration, low water retention, low biological activity, and low fertility, impacting strongly on root's growth (Traoré et al., 2000). This adversely affects crop yields due to alterations of physical, chemical and biological properties of soil (Ferrer and López, 2004). However, the addition of large amounts of organic matter (OM) can effectively improve physical properties of a degraded soil (Lamey and Janzen, 1996). Organic matter is vital for developing macroaggregates, which are required to provide a good porous system, especially needed to allow water seeping into soil, thus obtaining a better aeration and water retention (Ellies, 2004).

${ }^{1}$ Universidad de Concepción, Facultad de Agronomía, Casilla 537, Chillán, Chile.

${ }^{2}$ Universidad de Concepción, Facultad de Ciencias Veterinarias, Casilla 537, Chillán, Chile. "Corresponding author (jcelis@udec.cl). Received: 20 March 2012.

Accepted: 27 June 2012.
Local studies have proved that organic materials can improve physical, chemical and biological properties of Alfisols due to its high OM content (Sandoval et al., 2011; Celis et al., 2011a; 2011b). Nationwide, around $300 \mathrm{t} \mathrm{d}^{-1}$ of dry sewage sludge is currently produced at wastewater plants (Celis et al., 2008). Therefore, it is necessary to seek alternatives that allow re-using these wastes due to the serious environmental problem that can be generated. Soil degradation can be reversed through the process of formation of macroaggregates (Bayhan et al., 2005). Biota and organic products contribute to the development of soil structure (Chan et al., 2003), which has a key role in any soil system and biota sustained processes on the soil, and can be quantified through the stability of soil aggregates (Bronick and Lal, 2005; Sandoval-Estrada et al., 2008). Aggregate stability is an indicator of the soil structure, resulting from the arrangement of particles, flocculation and cementation (Six et al., 2000). The contribution of $\mathrm{OM}$ and increased aggregate stability can reduce the soil tendency to compaction and increase soil resistance to deformation because degradation is largely controlled by the presence and abundance of macroaggregates stable in water (Bayhan et al., 2005). The presence of glomalin, which is a glycoprotein produced by arbuscular mycorrhizal fungi, is an important agent involved in the stabilization of aggregates (Borie et al., 2000; Curaqueo et al., 2010). 
While sewage sludge provide beneficial properties to soil, one of the limitations when amended to soil is the concentration of trace elements and biological contaminants that could be harmful to human health (Castro et al., 2007) and crop development (Zapata et al., 2005). One study stated that sewage sludge applied at 40 $\mathrm{Mg} \mathrm{ha}^{-1}$ for $3 \mathrm{yr}$ showed no biological contamination and showed no translocation of trace elements into the aerial parts of crops as oats, wheat, corn, and tomato (Tapia, 2005). Bioassays of phytotoxicity performed in degraded Alfisols and Entisols have shown that up to $100 \mathrm{Mg} \mathrm{ha}^{-1}$ of sewage sludge did not affect germination of lettuce, even encouraging the development of aboveground biomass of annual ryegrass (Celis et al., 2008). In Chile environmental regulations state that sewage sludge must be amended to soils at maximum dose of $90 \mathrm{Mg} \mathrm{ha}^{-1}$ (DS 4, 2009), depending on the initial amount of heavy metals and physico-chemical conditions of the soil. Moreover, the Department of Agriculture subsidizes different activities that can be applied on degraded soils such as the application of liming amendment and the establishment of grassland or no-till, but does not fund the use of sewage sludge (Sandoval-Estrada et al., 2010). Biosolids can be applied as amendments in combination with materials such as sand or sawdust (Civeira and Lavado, 2006). Sawdust tends to favor water retention in heavy textured soils and contributes to the dynamics of nutrients elements and exchangeable bases (Grez y Gerding, 1995). Sawdust mixed with organic waste can improve physical, chemical, and nutritional properties of soils (Valenzuela and Andrade, 2002). A study showed that sawdust can improve the physical characteristics of pig slurry (Varnero et al., 2007). However, in Chile there are no studies showing that the amendments with sewage sludge mixed with sawdust in degraded Alfisol increases macroaggregates and soil available water content.

Consequently, the aim of this study was to assess the effect of the contributions of different doses of amended sewage sludge mixed with sawdust on the formation of soil aggregates, the stability of macroaggregates and available water content of a degraded Alfisol and cropped with hybrid ryegrass.

\section{MATERIALS AND METHODS}

\section{Soils, sludge and sawdust}

Soil samples were taken between 0-20 $\mathrm{cm}$ deep in an area near Chillán ( $36^{\circ} 37^{\prime}$ S, $72^{\circ} 19^{\prime}$ W), Bío-Bío Region, Chile. These soils correspond to a fine, kaolinitic, thermic Ultic Palexeralfs, commonly clayey texture, granite, low water infiltration into the profile, low vegetation, and topography of rolling hills, slopes generally $>15 \%$, and a bulk density of $1.6 \mathrm{~g} \mathrm{~cm}^{-3}$ (Stolpe, 2006).

Sewage sludge (LU) used in this study came from the wastewater plant located in city of Chillán (36 $36^{\circ}$
$\mathrm{S}, 72^{\circ} 07^{\prime} \mathrm{W}$ ). This material is defined as sludge class $\mathrm{B}$, suitable for beneficial application to soil and low microbiological concentration (Henríquez, 2005). Sawdust (RA) used in the amendment was from untreated pine wood (Pinus radiata D. Don), obtained from the local sawmill industries.

\section{Chemical characterization of soil and biosolids}

Soil and biosolids samples were dried at room temperature and sieved to $2 \mathrm{~mm}$. Chemical analyses were performed in laboratories of the Facultad de Agronomía, Universidad de Concepción, Chillán. The chemical characterization of soils was performed using the methodology proposed by Sadsawka et al. (2006), whereas for LU and RA methods proposed by Sadsawka et al. (2005) were used. Table 1 shows the results of the initial chemical analysis of soil and LU, and Table 2 for RA. The analysis to determine the concentration of heavy metals in LU was conducted in laboratory (accredited ISO 17025) at EULA-Chile of the Universidad de Concepción. The values of the analysis showed levels below to those required by the national environmental regulations (DS 4, 2009).

\section{Establishment of assay and treatments}

The trial was performed in pots under greenhouse conditions at Faculty of Agronomy of the University of Concepción. Samples of soil, sludge, and sawdust were sieved to $2 \mathrm{~mm}$. Homogeneous mixtures were made of 1 $\mathrm{kg}$ of soil with different doses of the LU/RA amendment according to the treatment. These prepared mixtures were placed in pots and distilled water was added to achieve $70 \%$ field capacity, and then covered with a polythene bag and incubated for $30 \mathrm{~d}$ at $25 \pm 2{ }^{\circ} \mathrm{C}$. Subsequently, the soil was seeded with hybrid ryegrass (Lolium $\times$ hybridum

Table 1. Initial chemical characterization of soil and sewage sludge.

\begin{tabular}{lcr}
\hline Parameter & Alfisol & \multicolumn{1}{c}{ LU } \\
\hline $\mathrm{pH}$ (water) & 5.60 & 5.94 \\
Organic matter, \% & 2.53 & 41.95 \\
$\mathrm{NO}_{3}-\mathrm{N}, \mathrm{mg} \mathrm{kg}^{-1}$ & 6.50 & 17.10 \\
$\mathrm{NH}_{4}-\mathrm{N}, \mathrm{mg} \mathrm{kg}^{-1}$ & 3.30 & 424.00 \\
$\mathrm{~N} \mathrm{available,} \mathrm{mg} \mathrm{kg}$ & 441.10 \\
$\mathrm{P}-$ Olsen, mg kg-1 & 9.80 & 853.20 \\
$\mathrm{~K}$ available, mg kg-1 & 5.40 & 5591.00 \\
Sum of bases, cmol kg-1 & 129.80 & 42.67 \\
$\mathrm{~N}$ total, \% & 5.47 & 5.47 \\
ECEC, cmol kg-1 $^{-1}$ & 0.15 & 42.69 \\
Ratio C/N & 5.49 & 4.50 \\
\hline
\end{tabular}

LU: Sewage sludge; ECEC: Effective cation exchange capacity.

Table 2. Chemical characterization of the sawdust.

\begin{tabular}{lr}
\hline Parameter & RA \\
\hline $\mathrm{pH}$ (water) & 5.82 \\
$\mathrm{OM}, \%$ & 88.01 \\
$\mathrm{NO}_{3}-\mathrm{N}, \mathrm{mg} \mathrm{kg}^{-1}$ & 1.20 \\
$\mathrm{NH}_{4}-\mathrm{N}, \mathrm{mg} \mathrm{kg}^{-1}$ & 7.60 \\
$\mathrm{~N}$ available, mg kg-1 & 8.80 \\
$\mathrm{~N}$ total, \% & 0.06 \\
$\mathrm{EC}, \mathrm{dS} \mathrm{m}{ }^{-1}$ & 0.20 \\
Ratio C/N & 875.2 \\
\hline
\end{tabular}

OM: Organic matter; EC: electrical conductivity; RA: sawdust. 
Hausskn. cv. Belinda) according to assigned treatment, with a dose of $1 \mathrm{~g}$ seed per pot. Twelve treatments were designed with different organic mixtures (LU/RA), in two doses of LU (25 and $50 \mathrm{Mg} \mathrm{ha}^{-1}$ ) and three doses of RA $\left(10,25\right.$, and $\left.50 \mathrm{Mg} \mathrm{ha}^{-1}\right)$. Four treatments were prepared with LU at doses of 25 and $50 \mathrm{Mg} \mathrm{ha}^{-1}$. Moreover, two treatments with synthetic fertilizer $\left(196 \mathrm{~kg} \mathrm{~N} \mathrm{ha}^{-1}, 100 \mathrm{~kg}\right.$ $\mathrm{P}_{2} \mathrm{O}_{5} \mathrm{ha}^{-1}$, and $90 \mathrm{~kg} \mathrm{~K}_{2} \mathrm{O} \mathrm{ha}^{-1}$ ) were prepared. Half of all treatments were planted with L. $\times$ hybridum.

The pots were maintained at $20 \pm 2{ }^{\circ} \mathrm{C}$ and wetted to keep soil at $70 \%$ of field capacity. The ryegrass was cut four times during the 6-mo experiment period $(2 \mathrm{~cm}$ residual height). Soil macroaggregates (MA), waterstable aggregates (AWG), available soil water content (AW), and aboveground biomass of L. $\times$ hybridum were evaluated.

\section{Aggregate distribution and stability}

The soil of each pot was dried at room temperature $(20 \pm$ $2{ }^{\circ} \mathrm{C}$ ); soil samples were taken and dried in an oven at 40 ${ }^{\circ} \mathrm{C}$ for $24 \mathrm{~h}$ (Le Bissonnais, 1996), and passed through a 4 $\mathrm{mm}$ sieve. Then $100 \mathrm{~g}$ of each sample were transferred to a set of sieves, from larger to smaller: 2.0, 1.0, 0.5, 0.25, and $0.05 \mathrm{~mm}$ (diameter). The sieves were immersed 15 min in water and shaken at 25 cycles $\min ^{-1}$ (Yoder, 1936).

Since this soil has a high amount of quartz gravel, it was necessary to discount the sand and gravel fraction of each sample, following the method proposed by SandovalEstrada et al. (2010). For this, the content of aggregates on each sieve was placed in a $50 \mathrm{~mL}$ jar, and then added $0.5 \mathrm{~N} \mathrm{NaOH}$ for $24 \mathrm{~h}$. The sample was mechanically shaken for $2 \mathrm{~min}$ at 15000 cycles $\mathrm{min}^{-1}$, to disintegrate the aggregates into basic particles. Then these particles were passed by a constant flow of water through a 0.05 $\mathrm{mm}$ sieve. Once separated, the sand fraction was dried at $105^{\circ} \mathrm{C}$ for $24 \mathrm{~h}$; it was deducted from the original mass of aggregates obtained by sieving. Thus, macroaggegates (MA) were calculated as the percentage of all those particles $\geq 0.25 \mathrm{~mm}$ (Oades and Waters, 1991). Waterstability of MA was determined using AWD parameter, suggested by Kemper and Rosenau (1986).

\section{Soil available water content}

The samples from the pots were air dried and sieved to 2 $\mathrm{mm}$, then taken to laboratory for examination. We used the method described by Klute (1986), which consisted on placing $25 \mathrm{~g}$ of soil for each treatment in rubber rings, which were placed on ceramic plates and placed in a pressure chamber. Subsequently, they were soaked in water for $24 \mathrm{~h}$ by capillary action. After this period, they were pressured at $3.3 \mathrm{MPa}$ and 148.5 MPa, corresponding to field capacity (CC) and permanent wilting point (PMP), respectively. The difference between $\mathrm{CC}$ and PMP expressed the soil available water content (AW). The value of AW is the amount of water useful and available into soil ready to be used by plants.

\section{Experimental design}

The experimental design was completely randomized with a factorial arrangement of $2 \times 9$ (ryegrass $\times$ rates of sludge and sawdust application). The results (three replicates per treatment) were analyzed using the ANOVA ( $\mathrm{p} \leq$ 0.05). Significant differences of means values between treatments were performed by Tukey's test. Values were transformed with the expression $(\mathrm{x}+0.5)^{0.5}$ to enter data to the program SAS 8.1 for Windows (SAS Institute, Cary, North Carolina, USA).

\section{RESULTS AND DISCUSSION}

\section{Aggregate distribution and macroaggregates stability}

The results of ANOVA (Table 3) showed responses ( $\mathrm{p} \leq$ 0.05 ) for both MA and AWD. There was no interaction between factors $(\mathrm{A} \times \mathrm{B})$, because they were analyzed in two groups: treatments with and without ryegrass at different doses of LU and RA.

Among treatments without ryegrass, $\mathrm{LU}_{25} / \mathrm{RA}_{10}$, $\mathrm{LU}_{50} / \mathrm{RA}_{25}$, and $\mathrm{LU}_{50} / \mathrm{RA}_{50}$ amendments significantly increased the formation of MA as compared to FI (Table 4). The rest of the treatments showed no significant

Table 3. ANOVA for macroaggregates (MA) and average weight diameter (AWD).

\begin{tabular}{llc}
\hline & \multicolumn{2}{c}{ F value } \\
\cline { 2 - 3 } Variation source & MA & AWD (mm) \\
\hline Hybrid ryegrass (A) & $5.20^{*}$ & $5.32^{*}$ \\
LU/RA amendment (B) & $4.14^{*}$ & $8.41^{*}$ \\
A*B & $1.93^{\text {ns }}$ & $1.93^{\text {ns }}$ \\
\hline
\end{tabular}

"Significant difference ( $\mathrm{p} \leq 0.05)$; LU/RA: Sewage sludge/sawdust; ${ }^{\text {ns: }}$ non significant.

Table 4. Aggregate distribution (\%) and average weight diameter (AWD) for different treatments applied in an Alfisol.

\begin{tabular}{|c|c|c|c|c|c|c|c|}
\hline \multirow[b]{2}{*}{ Treatments } & \multicolumn{7}{|c|}{ Sieve opening $(\mathrm{mm})$} \\
\hline & $4-2$ & $2-1$ & $1-0.5$ & $0.5-0.25$ & $<0.25$ & MA & AWD \\
\hline & & & & $-\%$ & & & $\mathrm{~mm}$ \\
\hline \multicolumn{8}{|l|}{ Without ryegrass: } \\
\hline FI & 0.1 & 1.4 & 3.0 & 9.4 & 16.9 & $13.8 \mathrm{~b}$ & $0.22 \mathrm{c}$ \\
\hline $\mathrm{LU}_{25}$ & 0.2 & 2.2 & 9.9 & 10.0 & 13.2 & $22.2 \mathrm{ab}$ & $0.32 \mathrm{bc}$ \\
\hline $\mathrm{LU}_{25} / \mathrm{RA}_{10}$ & 0.1 & 2.6 & 6.5 & 15.0 & 13.9 & $24.1 \mathrm{a}$ & $0.28 \mathrm{c}$ \\
\hline $\mathrm{LU}_{25} / \mathrm{RA}_{25}$ & 0.1 & 2.9 & 6.2 & 12.1 & 13.3 & $21.3 \mathrm{ab}$ & $0.30 \mathrm{c}$ \\
\hline $\mathrm{LU}_{25} / \mathrm{RA}_{50}$ & 0.3 & 2.6 & 7.3 & 12.1 & 13.4 & $22.2 \mathrm{ab}$ & $0.34 \mathrm{ab}$ \\
\hline $\mathrm{LU}_{50}$ & 0.5 & 3.5 & 8.7 & 9.5 & 8.7 & $22.2 \mathrm{ab}$ & $0.39 \mathrm{ab}$ \\
\hline $\mathrm{LU}_{50} / \mathrm{RA}_{10}$ & 0.9 & 3.0 & 6.6 & 12.5 & 10.7 & $23.0 \mathrm{ab}$ & $0.36 \mathrm{ab}$ \\
\hline $\mathrm{LU}_{50} / \mathrm{RA}_{25}$ & 1.5 & 5.9 & 8.0 & 9.8 & 9.1 & $25.1 \mathrm{a}$ & $0.47 \mathrm{ab}$ \\
\hline $\mathrm{LU}_{50} / \mathrm{RA}_{50}$ & 1.5 & 5.6 & 7.6 & 11.3 & 6.5 & $25.9 \mathrm{a}$ & $0.48 \mathrm{a}$ \\
\hline $\mathrm{CV}(\%)$ & & & & & & 15.0 & 15.3 \\
\hline \multicolumn{8}{|l|}{ With ryegrass: } \\
\hline FI-P & 0.6 & 3.4 & 5.8 & 12.5 & 10.6 & $22.4 \mathrm{ab}$ & $0.36 \mathrm{~b}$ \\
\hline $\mathrm{LU}_{25}-\mathrm{P}$ & 0.6 & 3.0 & 6.3 & 10.2 & 15.6 & $20.1 b$ & $0.29 \mathrm{c}$ \\
\hline $\mathrm{LU}_{25} / \mathrm{RA}_{10}-\mathrm{P}$ & 0.6 & 3.7 & 5.9 & 10.1 & 13.5 & $20.3 b$ & $0.34 \mathrm{bc}$ \\
\hline $\mathrm{LU}_{25} / \mathrm{RA}_{25}-\mathrm{P}$ & 0.7 & 3.3 & 7.2 & 11.7 & 14.4 & $22.8 \mathrm{ab}$ & $0.33 \mathrm{bc}$ \\
\hline $\mathrm{LU}_{25} / \mathrm{RA}_{50}-\mathrm{P}$ & 0.5 & 4.7 & 9.5 & 10.1 & 8.0 & $24.7 \mathrm{ab}$ & $0.41 \mathrm{~b}$ \\
\hline $\mathrm{LU}_{50}-\mathrm{P}$ & 2.3 & 5.5 & 9.4 & 10.2 & 9.2 & $27.5 \mathrm{ab}$ & $0.50 \mathrm{a}$ \\
\hline $\mathrm{LU}_{50} / \mathrm{RA}_{10}-\mathrm{P}$ & 1.0 & 2.7 & 11.5 & 10.9 & 12.7 & $26.1 \mathrm{ab}$ & $0.37 \mathrm{~b}$ \\
\hline $\mathrm{LU}_{50} / \mathrm{RA}_{25}-\mathrm{P}$ & 2.0 & 3.8 & 6.6 & 12.5 & 10.7 & $24.9 \mathrm{ab}$ & $0.42 b$ \\
\hline $\mathrm{LU}_{50} / \mathrm{RA}_{50}-\mathrm{P}$ & 1.2 & 5.5 & 11.2 & 11.7 & 8.2 & $29.7 a$ & $0.45 \mathrm{ab}$ \\
\hline $\mathrm{CV}, \%$ & & & & & & 12.1 & 13.9 \\
\hline
\end{tabular}

MA: Macroaggregates ( $\geq 0.25 \mathrm{~mm})$; FI: synthetic fertilizer; LUi: sewage sludge at dose $\left(\mathrm{Mg} \mathrm{ha}^{-1}\right)$; LUi/RAj: sewage sludge at dose i $\left(\mathrm{Mg} \mathrm{ha}^{-1}\right)$ with sawdust at dose $\mathrm{j}\left(\mathrm{Mg} \mathrm{ha}^{-1}\right)$; FI$\mathrm{P}$ : synthetic fertilizer and ryegrass; LUi-P: sewage sludge at dose $\mathrm{i}\left(\mathrm{Mg} \mathrm{ha}^{-1}\right)$ and ryegrass; $\mathrm{LUi} / \mathrm{RAj}-\mathrm{P}$ : sewage sludge at dose $\mathrm{i}\left(\mathrm{Mg} \mathrm{ha}^{-1}\right)$ with sawdust at dose $\mathrm{j}\left(\mathrm{Mg} \mathrm{ha}^{-1}\right)$ and ryegrass; $\mathrm{CV}$ : coefficient of variation.

Different letters in columns indicate significant differences $(\mathrm{p} \leq 0.05)$. 
differences. Regarding water-stable aggregates, $\mathrm{LU}_{50} \mathrm{~A}_{50}$ was statistically greater $(\mathrm{p} \leq 0.05)$ as compared to FI, increasing significantly AWD (118\%). Even synthetic fertilizer that promotes root development does not improve macroaggregate stability because it is not incorporating any OM. Contributions of 5\% of LU can increase AWD up to $78 \%$ as compared to its initial condition (Guerrero et $a l ., 2001)$. The $\mathrm{OM}$ acts as a cementing agent in the process of aggregation (Bronick and Lal, 2005), agglutinating particles and increasing stability of macroaggregates (Six et al., 2000).

A trend was noted as amended treatments with ryegrass showed higher values for macroaggregates and water-stability aggregates. The reason is because both parameters are strongly improved by roots and OM (Carter, 2004). The presence of roots increased soil aggregation in almost all treatments. This effect is reinforced by high OM content when organic residues are amended, thus improving physical properties of the soils (Ellies, 2004). On the other hand, exudates and cementing agents released by roots and microorganisms, such as fungi and some bacteria, improve stability of macroaggregates (Schreiner and Bethlenfalvay, 1995).

The results show that sewage sludge with sawdust increased macroaggregates and macroaggregate stability compared to inorganic fertilizer. These results are in agreement with Sandoval-Estrada et al. (2010), who reported similar responses in Entisols and Alfisols amended with sewage sludge and salmon wastes. Other studies have reported improvements in the structure of degraded soils that were amended with different biosolids mixed with inert materials (Civeira and Lavado, 2006). The OM has a key role in the formation and stability of macroaggregates (Tisdall and Oades, 1982), and protects soil against soil erosion (Roldán et al., 1996). Additionally, the contribution of MO is a primary source of microbial biomass $\mathrm{C}$ and soil fungus (García-Oliva et al., 2004), important agents in the formation of the structure (Curaqueo et al., 2010).

The highest values of aboveground biomass (Table 5) corresponded to treatment with higher doses of LU and $\mathrm{RA}\left(\mathrm{LU}_{50} / \mathrm{RA}_{50}-\mathrm{P}\right.$ and $\left.\mathrm{LU}_{50} / \mathrm{RA}_{25}-\mathrm{P}\right)$. In contrast, the FI-P

Table 5. Aboveground biomass (dry weight) of Lolium hibridum in treatments with different amendments of sewage sludge and sawdust in an Alfisol.

\begin{tabular}{lc}
\hline Treatments & Aboveground biomass $(\mathrm{g})$ \\
\hline FI-P & $18.4 \mathrm{c}$ \\
$\mathrm{LU}_{25}-\mathrm{P}$ & 42.9 \\
$\mathrm{LU}_{25} / \mathrm{RA}_{10}-\mathrm{P}$ & $45.6 \mathrm{ab}$ \\
$\mathrm{LU}_{25} / \mathrm{RA}_{25}-\mathrm{P}$ & $35.9 \mathrm{~b}$ \\
$\mathrm{LU}_{25} / \mathrm{RA}_{50}-\mathrm{P}$ & $40.4 \mathrm{~b}$ \\
$\mathrm{LU}_{50}-\mathrm{P}$ & $48.2 \mathrm{ab}$ \\
$\mathrm{LU}_{50} / \mathrm{RA}_{10}-\mathrm{P}$ & $47.2 \mathrm{ab}$ \\
$\mathrm{LU}_{50} / \mathrm{RA}_{25}-\mathrm{P}$ & $56.6 \mathrm{a}$ \\
$\mathrm{LU}_{50} / \mathrm{RA}_{50} \mathrm{P}$ & $55.8 \mathrm{a}$ \\
$\mathrm{CV}, \%$ & 9.8 \\
\hline
\end{tabular}

FI-P: synthetic fertilizer and ryegrass; LUi-P: sewage sludge at dose $\mathrm{i}\left(\mathrm{Mg} \mathrm{ha}^{-1}\right)$ and ryegrass; $\mathrm{LUi} / \mathrm{RAj}-\mathrm{P}$ : sewage sludge at dose $\mathrm{i}\left(\mathrm{Mg} \mathrm{ha}^{-1}\right)$ with sawdust at dose $\mathrm{j}\left(\mathrm{Mg} \mathrm{ha}^{-1}\right)$ and ryegrass; $\mathrm{CV}$ : coefficient of variation.

Different letters in columns indicate significant differences $(\mathrm{p} \leq 0.05)$ treatment showed the lowest biomass production. This clearly shows the importance of adding $\mathrm{OM}$ and also nutrients to a degraded soil by adding biosolids. Organic matter is important for creating favorable conditions for plant growth (Ferrer and López, 2004). The use of sludge allows adding valuable nutritional compounds for plants, such as P, N, and K (Zufiaurre et al., 1998). A greater aboveground biomass can avoid nitrate leaching, thus diminishing any risk for groundwater contamination (Celis et al., 2008).

\section{Soil available water content}

Table 6 shows differences $(\mathrm{p} \leq 0.05)$ for AW among treatments, so indicating that the presence of ryegrass (A) and amendments LU/RA (B) had positive effects on both $\mathrm{CC}$ and PMP. There was interaction $(\mathrm{p} \leq 0.05)$ between factors $\mathrm{A}$ and $\mathrm{B}$, so the data were evaluated together for treatments with and without ryegrass.

According to Table 7, treatments with sewage sludge and sawdust mixed at different rates showed higher available water content (6.31 against 5.74) when added to soil in the presence of hybrid ryegrass. This is so due mainly to increased OM at highest doses of LU along with roots, thus favoring macroaggregates and available water content (Oades and Waters, 1991;

Table 6. ANOVA for soil water content in an Alfisol amended with sewage sludge and sawdust.

\begin{tabular}{lrlr}
\hline & \multicolumn{3}{l}{ F value } \\
\cline { 2 - 4 } Variation source & CC & PMP & AW \\
\hline Hybrid ryegrass (A) & $48.81^{*}$ & $47.41^{*}$ & $20.66^{*}$ \\
LU/RA amendment (B) & $20.90^{*}$ & $21.38^{*}$ & $11.23^{*}$ \\
A $\times$ B & $5.01^{*}$ & $13.30^{*}$ & $2.78^{*}$ \\
\hline
\end{tabular}

CC: field capacity at $3.3 \mathrm{MPa}$; PMP: permanent wilting point at $148.5 \mathrm{MPa}$; $\mathrm{AW}$ : available water content (CC-PMP); LU/RA: sewage sludge/sawdust.

${ }^{*}$ Significant difference $(\mathrm{p} \leq 0.05)$.

Table 7. Field capacity (CC), permanent wilting point (PMP) and available water content (AW) in an Alfisol amended with sewage sludge and sawdust.

\begin{tabular}{lccc}
\hline & \multicolumn{3}{c}{ Soil water content (\%, dry weight) } \\
\cline { 2 - 4 } Treatments & $\mathrm{CC}$ & $\mathrm{PMP}$ & $\mathrm{AW}$ \\
\hline $\mathrm{FI}$ & $15.5 \mathrm{c}$ & $10.3 \mathrm{c}$ & $5.4 \mathrm{c}$ \\
$\mathrm{LU}_{25}$ & $15.8 \mathrm{bc}$ & $10.3 \mathrm{c}$ & $5.6 \mathrm{c}$ \\
$\mathrm{LU}_{25} / \mathrm{RA}_{10}$ & $15.4 \mathrm{c}$ & $10.2 \mathrm{c}$ & $5.2 \mathrm{c}$ \\
$\mathrm{LU}_{25} / \mathrm{RA}_{25}$ & $15.5 \mathrm{c}$ & $10.4 \mathrm{c}$ & $5.1 \mathrm{c}$ \\
$\mathrm{LU}_{25} / \mathrm{RA}_{50}$ & $15.2 \mathrm{c}$ & $10.1 \mathrm{c}$ & $5.1 \mathrm{c}$ \\
$\mathrm{LU}_{50}$ & $16.4 \mathrm{bc}$ & $10.8 \mathrm{bc}$ & $5.6 \mathrm{c}$ \\
$\mathrm{LU}_{50} / \mathrm{RA}_{10}$ & $16.8 \mathrm{bc}$ & $10.6 \mathrm{c}$ & $6.2 \mathrm{bc}$ \\
$\mathrm{LU}_{50} / \mathrm{RA}_{25}$ & $16.5 \mathrm{bc}$ & $10.4 \mathrm{c}$ & $6.1 \mathrm{bc}$ \\
$\mathrm{LU}_{50} / \mathrm{RA}_{50}$ & $17.9 \mathrm{~b}$ & $11.0 \mathrm{bc}$ & $6.9 \mathrm{ab}$ \\
$\mathrm{FI}^{-\mathrm{P}}$ & $17.2 \mathrm{bc}$ & $10.9 \mathrm{bc}$ & $6.3 \mathrm{bc}$ \\
$\mathrm{LU}_{25}-\mathrm{P}$ & $15.8 \mathrm{bc}$ & $10.4 \mathrm{c}$ & $5.4 \mathrm{c}$ \\
$\mathrm{LU}_{25} / \mathrm{RA}_{10}-\mathrm{P}$ & $15.9 \mathrm{bc}$ & $10.3 \mathrm{c}$ & $5.6 \mathrm{c}$ \\
$\mathrm{LU}_{25} / \mathrm{RA}_{25}-\mathrm{P}$ & $16.4 \mathrm{bc}$ & $10.5 \mathrm{c}$ & $5.9 \mathrm{c}$ \\
$\mathrm{LU}_{25} / \mathrm{RA}_{50}-\mathrm{P}$ & $16.5 \mathrm{bc}$ & $10.7 \mathrm{bc}$ & $5.7 \mathrm{c}$ \\
$\mathrm{LU}_{50}-\mathrm{P}$ & $16.2 \mathrm{bc}$ & $10.4 \mathrm{c}$ & $5.8 \mathrm{c}$ \\
$\mathrm{LU}_{50} / \mathrm{RA}_{10}-\mathrm{P}$ & $18.5 \mathrm{~b}$ & $11.3 \mathrm{bc}$ & $7.2 \mathrm{ab}$ \\
$\mathrm{LU}_{50} / \mathrm{RA}_{25}-\mathrm{P}$ & $19.7 \mathrm{ab}$ & $12.2 \mathrm{~b}$ & $7.5 \mathrm{a}$ \\
$\mathrm{LU}_{50} / \mathrm{RA}_{50}-\mathrm{P}$ & $21.8 \mathrm{a}$ & $15.3 \mathrm{a}$ & $6.5 \mathrm{ab}$ \\
$\mathrm{CV}_{1} \%$ & 4.5 & 4.5 & 7.2 \\
\hline
\end{tabular}

FI: synthetic fertilizer; LUi: sewage sludge at dose i $\left(\mathrm{Mg} \mathrm{ha}^{-1}\right)$; LUi/RAj: sewage sludge at dose $\mathrm{i}\left(\mathrm{Mg} \mathrm{ha}^{-1}\right)$ with sawdust at dose $\mathrm{j}\left(\mathrm{Mg} \mathrm{ha}^{-1}\right)$; FI-P: synthetic fertilizer and ryegrass; LUi-P: sewage sludge at dose i $\left(\mathrm{Mg} \mathrm{ha}^{-1}\right)$ and ryegrass; LUi/RAj-P: sewage sludge at dose $\mathrm{i}\left(\mathrm{Mg} \mathrm{ha}^{-1}\right)$ with sawdust at dose $\mathrm{j}\left(\mathrm{Mg} \mathrm{ha}^{-1}\right)$ and ryegrass; $\mathrm{CV}$ : coefficient of variation. Different letters in columns indicate significant differences $(\mathrm{p} \leq 0.05)$. 
Bronick and Lal, 2005). The highest LU dose (50 Mg ha $^{-1}$ ) resulted in highest AW, especially when LU was mixed with RA at different doses $(10,25$, and $50 \mathrm{Mg}$ ha $\left.{ }^{1}\right)$. LU/RA at highest dose (50 $\mathrm{Mg} \mathrm{ha}^{-1}$ each) increased AW about $39 \%$ when compared to FI-P, which means that $\mathrm{OM}$ improved $\mathrm{AW}$. Even RA has a high $\mathrm{C} / \mathrm{N}$ ratio, when mixed with LU (which has a low $\mathrm{C} / \mathrm{N}$ ), produced a balanced amendment thus increasing AW. Some studies have shown an increase in water retention due to the addition of sawdust in sandy soils, and increased soil nutrient level (Grez y Gerding, 1995). According to Bauer and Black (1994), when OM increased also did AW in sandy textured soils. Similar results have been found in Inceptisols (Ferrer and López, 2004). Finally, it is very interesting that such organic residues increased AW after being amended to soil, especially if Alfisols tested in this study are an important resource of drylands, characterized for low precipitations during most of the year.

\section{CONCLUSIONS}

Sewage sludge combined with sawdust and then amended to soil, increased macroaggregates and also their stability, effect which was more significant at the highest dose tested for both organic residues. There was greater plant available water content when soil was amended with sewage sludge combined with any of the dose of sawdust studied. Ryegrass aboveground biomass increased directly with increasing doses of sewage sludge and sawdust in the mix. The positive effects on the macroaggregation, water-stable aggregates and available water content were especially noted when sewage sludge and sawdust were mixed and so added to soil, in the presence of Lolium $x$ hybridum.

\section{ACKNOWLEDGEMENT}

This study (project 208.153.018-1.0) was funded by the Dirección de Investigación of the Universidad de Concepción, Chile.

Efectos de lodos urbanos y aserrín en asociación con ballica (Lolium $\times$ hybrydum Hausskn.) sobre los microagregados y contenido de agua del suelo. La degradación de los suelos chilenos es un serio problema que afecta directamente la productividad de la mayoría de los cultivos. Los lodos urbanos pueden mejorar las propiedades físicas del suelo, sobre todo si van acompañadas con aserrín. El objetivo fue evaluar el efecto de distintas mezclas de lodo urbano (LU) y aserrín (RA) sobre los agregados estables al agua y el contenido de agua disponible en un Alfisol degradado y cultivado con ballica híbrida (Lolium $\times$ hybridum Hausskn.), bajo invernadero. El diseño experimental fue completamente al azar con un arreglo factorial $2 \times 9$ (ballica híbrida $\times$ dosis de lodo y aserrín). Los tratamientos fueron: 25 y $50 \mathrm{Mg}$ ha $^{-1}$ de LU en mezcla con 10, 25 y $50 \mathrm{Mg} \mathrm{ha}^{-1}$ de RA. Las mezclas LU/RA se enmendaron en macetas con ballica híbrida. Se evaluó el contenido de agua disponible (AW), el porcentaje de macroagregados (MA) y la estabilidad de los macroagregados al agua (AWD). También se midió la producción de fitomasa aérea. Las mezclas de LU/ RA enmendadas al suelo aumentaron los MA y el AWD, efecto que fue más evidente a $50 \mathrm{Mg} \mathrm{ha}^{-1}$. El valor de $\mathrm{AW}$ fue mayor cuando se enmendó $50 \mathrm{Mg} \mathrm{LU}$ ha $^{-1}$ en mezcla con RA a dosis de 10,25 y $50 \mathrm{Mg} \mathrm{ha}^{-1}$. Hubo mayor biomasa aérea de ballica híbrida, en directa relación con el incremento de las dosis de LU y RA en las mezclas. La adición de LU y RA en mezclas combinadas al suelo mejoraron los parámetros físicos evaluados, especialmente en presencia de ballica híbrida.

Palabras clave: agregación del suelo, biosólidos, remediación, residuos orgánicos.

\section{LITERATURE CITED}

Bauer, A., and A.L. Black. 1994. Quantification of the effect of soil organic matter content on soil productivity. Soil Science Society of America Journal 58:185-193.

Bayhan, A.K., A.A. Isisdar, and M. Akgül. 2005. Tillage impacts on aggregate stability and crop productivity in a loam soil of a dryland in Turkey. Acta Agriculturæ Scandinavica, Section B Soil and Plant Science 55:214-220.

Borie, F.R., R. Rubio, A. Morales, y C. Castillo. 2000. Relación entre densidad de hifas de hongos micorrizógenos arbusculares y producción de glomalina con las características físicas y químicas de suelos bajo cero labranza. Revista Chilena de Historia Natural 73:749-756.

Bronick, C.J., and R. Lal. 2005. Soil structure and management: a review. Geoderma 124:3-22.

Carter, M.R. 2004. Researching structural complexity in agricultural soil. Soil and Tillage Research 79:1-6.

Castro, C., O. Henríquez, y R. Freres. 2007. Posibilidades de aplicación de lodos o biosólidos a los suelos del sector norte de la Región Metropolitana de Santiago. Revista de Geografía Norte Grande 37:35-45.

Celis, J., A. Machuca, M. Sandoval, and P. Morales. 2011b. Biological activity in a degraded alfisol amended with sewage sludge and cropped with yellow serradela (Ornithopus compressus L.). Chilean Journal of Agricultural Research 71:164-172.

Celis, J., M. Sandoval, and R. Barra. 2008. Plant response to Salmon wastes and sewage sludge used as organic fertilizer on two degraded soil under greenhouse conditions. Chilean Journal of Agricultural Research 68:274-283.

Celis, J., M. Sandoval, and N. Bello. 2011a. No-linear respiration dynamics in a degraded Alfisol amended with different dose of salmon sludges. Chilean Journal of Agricultural Research 71:58 67.

Chan, K.Y., D.P. Heenan, and H.B. So. 2003. Sequestration of carbon and changes in soil quality under conservation tillage on light-textured soil in Australia: a review. Australian Journal of Experimental Agriculture 43:325-334.

Civeira, G., y R. Lavado. 2006. Efecto del aporte de enmiendas orgánicas sobre propiedades físicas e hidrológicas de un suelo urbano degradado. Ciencia del Suelo 24:123-130.

Curaqueo, G., E. Acevedo, P. Cornejo, A. Seguel, R. Rubio, and F. Borie. 2010. Tillage effect on soil organic matter, mycorrhizal hyphae and aggregates in a mediterranean agroecosystem. Revista de la Ciencia del Suelo y Nutrición Vegetal 10:12-21. 
DS 4. 2009. Reglamento para el manejo de lodos generados en plantas de tratamiento de aguas servidas. Ministerio Secretaría General de la Presidencia de la República, Santiago, Chile.

Ellies, A. 2004. Efecto de la materia orgánica sobre la estructura del suelo. p. 139-150. In M. Mora (ed.) Residuos orgánicos y su uso en sistemas agroforestales. Simposio de la Sociedad Chilena de la Ciencia del Suelo, Universidad de la Frontera, Temuco, Chile.

Ferrer, G., y R. López. 2004. Capacidad de retención de humedad de un Inceptisol de los andes venezolanos y su afectación por pérdida de suelo superficial y la adición de abono orgánico. Revista Forestal Venezolana 48:63-73.

García-Oliva, F., M. Oliva, and B. Sveshtarova. 2004. Effect of soil macroaggregates crushing on $\mathrm{C}$ mineralization in a tropical deciduous forest ecosystem. Plant and Soil 259:297-305.

Grez, R., y V. Gerding. 1995. Aplicación de aserrín de la industria forestal para el mejoramiento del suelo. Bosque 16:115-119.

Guerrero, C., J. Mataix-Solera, J. Navarro-Pedreño, F. GarcíaOrdenes, and I. Gómez. 2001. Different patterns of aggregate stability in burned and restored soils. Arid Land Research and Management 15:163-171.

Henríquez, O. 2005. Valoración de lodos provenientes de plantas de tratamiento de aguas servidas como mejoradoras de suelos degradados. pp: 91-110. In S. González et al. (eds.) Seminario uso benéfico de lodos. Proyecto valoración de lodos como fertilizantes. Serie actas INIA $\mathrm{N}^{\circ} 27$. Instituto de Investigaciones Agropecuarias, Santiago, Chile.

Kemper, W.D., and R.C. Rosenau. 1986. Aggregate stability and size distribution. p. 425-442. In Methods of soil analysis: part I. Physical and mineralogical methods. $2^{\text {nd }}$ ed. American Society Agronomy/Soil Science Society of America, Madison, Wisconsin, USA.

Klute, A. 1986. Water retention: laboratory methods. p. 635-662. In Methods of soil analysis: part I. Physical and mineralogical methods. $2^{\text {nd }}$ ed. American Society Agronomy/Soil Science Society of America, Madison, Wisconsin, USA.

Lamey, F., and H. Janzen. 1996. Restoration of productivity to desurfaced soil with livestock manure, crop residue and fertilizer amendments. Soil Science Society of America Journal 88:921927.

Le Bissonnais, Y. 1996. Aggregate stability and assessment of soil crustability and erodibility: I. Theory and methodology. European Journal of Soil Science 47:425-437.

Oades, J.M., and A.G. Waters. 1991. Aggregate hierarchy in soils. Australian Journal of Soil Research 29:815-828.

Pérez, C., y J. González. 2001. Diagnóstico sobre el estado de degradación del recurso suelo en el país. Boletín INIA $\mathrm{N}^{\circ} 15$. Instituto de Investigaciones Agropecuarias, CRI Quilamapu, Chillán, Chile.

Roldán, A., J. Albadalejo, and J.B. Thormes. 1996. Aggregate stability changes in a semiarid soil after treatment with different organic amendments. Arid Soil Research and Rehabilitation 10:139-148

Sadzawka, A., M. Carrasco, R. Grez, y M. Mora. 2005. Métodos de análisis de compost. Serie Actas $\mathrm{N}^{\circ} 30.142$ p. Instituto de Investigaciones Agropecuarias, Centro Regional de Investigación La Platina, Santiago, Chile.
Sadzawka, A., M. Carrasco, R. Grez, M. Mora, H. Flores, y A. Neaman. 2006. Métodos de análisis recomendados para los suelos de Chile. Serie Actas $N^{\circ} 30.164$ p. Instituto de Investigaciones Agropecuarias, Centro Regional de Investigación La Platina, Santiago, Chile.

Sandoval, M.A., J.E. Celis, and P. Morales. 2011. Structural remediation of an Alfisol by means of sewage sludge amendments in association with yellow serradela (Ornithopus compressus L.) Journal of Soil Science and Plant Nutrition 11:68-78.

Sandoval-Estrada, M., J. Celis-Hidalgo, N. Stolpe-Lau, y J. CapulínGrande. 2010. Efecto de enmiendas con lodos urbanos y de salmonicultura en la estructura de un Entisol y un Alfisol en Chile. Agrociencia 44:503-515.

Sandoval-Estrada, M., N. Stolpe-Lau, E. Zagal-Venegas, M. Mardones-Flores, y J. Celis-Hidalgo. 2008. Aporte de carbono orgánico de la labranza cero y su impacto en la estructura de un Andisol de la precordillera andina chilena. Agrociencia 42:139149.

Schreiner, R.P., and G.J. Bethlenfalvay. 1995. Mycorrhizal interactions in sustainable agriculture. Critical Review of Biotechnology 15:271-285.

Six, J., K. Paustian, E.T. Elliot, and C. Combrink. 2000. Soil structure and organic matter: I. Distribution of aggregate-size classes and aggregate-associated carbon. Soil Science Society of America Journal 64:681-689.

Stolpe, N.B. 2006. Descripciones de los principales suelos de la VIII Región de Chile. Universidad de Concepción, Facultad de Agronomía, Chillán, Chile.

Tapia, F. 2005. Valoración agrícola de lodos provenientes de plantas de tratamiento de aguas servidas, como fertilizante en cultivos anuales. p. 63-72. In S. González et al. (eds.) Seminario uso benéfico de lodos. Proyecto valoración de lodos como fertilizantes. Serie actas INIA $\mathrm{N}^{\circ} 27$. Instituto de Investigaciones Agropecuarias, Santiago, Chile.

Tisdall, J.M., and J.M. Oades. 1982. Organic matter and water-stable aggregates in soils. Journal of Soil Science 33:141-163.

Traoré, O., V. Groleau-Renaud, S. Plantureux, A. Tubeileh, and V. Boeuf-Tremblay. 2000. Effect of root mucilage and modelled root exudates on soil structure. European Journal of Soil Science 51:575-581.

Valenzuela, E., y N. Andrade. 2002. Cultivo de repollo en aserrín de pino tratado con cepas de agaricales. Boletín Micológico 17:7579.

Varnero, M., R. Zúñiga, y S. Muñoz. 2007. Valorización agrícola de purines de cerdo procesados con aserrín. p. 137-141. In XVII Congreso Latinoamericano de la Ciencia del Suelo, León, Guanajuato, México.

Yoder, R. 1936. A direct method of aggregate analysis of soils and a study of the physical nature of erosion losses. Agronomy Journal 28:337-351

Zapata, N., F. Guerrero, y A. Polo. 2005. Evaluación de corteza de pino y residuos urbanos como componentes de sustratos de cultivo. Agricultura Técnica (Chile) 65:378-387.

Zufiaurre, R., A. Olivar, P. Chamorro, C. Nerín, and A. Callizo. 1998. Speciation of metals in sewage sludge for agricultural uses. Analyst 123:255-259. 